\title{
ANALISIS DEIKSIS PADA NOVEL SANG PEMIMPI KARYA ANDREA HIRATA
}

\author{
Aslina Aci \\ SMA Negeri 3 Poco Ranaka \\ Pandang, Arus, Kec. Poco Ranaka Timur, Kab. Manggarai Timur, Indonesia \\ Pos-el : aslinaaci67@yahoo.com
}

\begin{abstract}
This study attempts to describe deiksis, persona deiksis, place deiksis, time deiksis discourse and deiksis socially on a novel Sang Pemimpi created by Andrea Hirata. The research is qualitative study. Data collection method used is a technique read and write down. Data in this study of novel titled Sang Pemimpi created by Andrea Hirata. Analysis technique is using a technique deskriptf analysis. From the data analysis, deiksis in a novel Sang Pemimpi. Persona deiksis having six part including; the first single pronouns (i), the second person single pronouns (you), demonstrative the third person singular (he), pronouns (we first plural, we), second plural pronouns (you), third plural pronouns (they). Deiksis place found in this experiment in which; here, there, in the market. Deiksis time found in the study of them now, now, last, first. Deiksis discourse found of them anaphora and katafora. While social deiksis found in the study is among them mrs, and b.a.
\end{abstract}

\begin{abstract}
ABSTRAK
Penelitian ini bertujuan untuk mendeskripsikan deiksis persona, deiksis tempat, deiksis waktu, deiksis wacana dan deiksis sosial pada novel Sang Pemimpi Karya Andrea Hirata. Jenis penelitian ini adalah penelitian kualitatif. Metode pengumpulan data yang digunakan adalah teknik membaca dan mencatat. Data dalam penelitian ini berupa novel yang berjudul Sang Pemimpi Karya Andrea Hirata. Teknik analisis adalah menggunakan teknik analisis deskriptf. Dari hasil analisis data, terdapat deiksis dalam novel Sang Pemimpi Karya Andrea Hirata. Deiksis persona memiliki enam bagian di antaranya; pronomina orang pertama tunggal (aku), pronomina orang kedua tunggal (kau), pronomina orang ketiga tunggal (dia), pronomina pertama jamak (kami, kita), pronomina kedua jamak (kalian), pronomina ketiga jamak (mereka). Deiksis tempat yang ditemukan dalam penelitian ini di antaranya; di sini, di situ, di pasar kumuh. Deiksis waktu yang ditemukan dalam penelitian ini diantaranya kini, sekarang, tadi, dulu. Deiksis wacana yang ditemukan diantaranya anafora dan katafora. Sedangkan deiksis sosial yang ditemukan dalam penelitian ini diantaranya Nyonya, dan B.A.
\end{abstract}

Kata Kunci : deiksis,

\section{PENDAHULUAN}

Bahasa menduduki peran penting dalam kehidupan manusia. Bahasa adalah sistem lambang bunyi yang dipergunakan oleh para anggota 
kelompok tertentu, dalam bekerja sama dan mengidentifikasi diri (Kridalaksana, 2008:3). Berdasarkan hal tersebut bahasa adalah alat yang digunakan oleh masyarakat untuk berkomunikasi dan beriteraksi. Dengan bahasa pula manusia dapat berkembang dan mengabstraksikan berbagai gejala yang muncul di lingkungannya. Dalam kehidupan manusia tidak dapat dilepaskan dari kegiatan berbahasa. Kegiatan berbahasa terdiri atas empat aspek keterampilan yaitu menyimak, berbicara, menulis dan membaca. Kegiatan berbahasa adalah kegiatan mengekspresikan lambang-lambang bahasa untuk menyampaikan makna-makna yang ada pada lambang bahasa kepada lawan bicara (dalam komunikasi lisan) atau pembacanya (dalam komunikasi tulis). Pengetahuan akan adanya hubungan antara lambang atau satuan bahasa dengan maknanya sangat diperlukan dalam berkomunikasi.

Upaya

penggunaan

pemahaman

komunikatif, mudah dipahami dan mencapai sasaran yang diinginkan. Dalam hal ini studi pragmatik sangat penting untuk dipelajari karena pragmatik merupakan studi tentang hubungan antara bentkbentuk linguistik dan pemakaian bentuk-bentuk itu (Yule, 2006:5). Pragmatik menelaah ucapanucapan khusus dalam situasisituasi khusus dan terutama sekali memusatkan perhatian pada aneka ragam cara yang merupakan wadah aneka konteks sosial perfomansi dapat mempengaruhi tafsiran atau interpretasi (Tarigan, 2008:32). Satu di antara studi pragmatik yang akan peneliti kaji dalam penelitian ini yakni deiksis.

Deiksis adalah kata, frasa, atau ungkapan yang rujukannya berpindah-pindah bergantung pada pembicara, waktu, dan tempat dituturkannya satuan bahasa tersebut. Kata deiksis berasal dari bahasa Yunani kuno yaitu deik "tunjuk", yang diambil dari kata deiknumi "menunjukan". artinya deiksis kini sudah semakin berkembang sesuai dengan perkembangan ilmu liguistik.
Deiksis dapat diartikan sebagai bentuk bahasa yang titik acuannya bergantung pada penutur. Kushartanti (2015:5) menjelaskan deiksis sebagai "cara menunjuk pada suatu hal yang berkaitan erat dengan konteks penutur. Dalam pragmatik, deiksis dibagi menjadi lima jenis meliputi; deiksis orang, deiksis waktu, deiksis tempat, deiksis wacana, deiksis sosial (Fitria, 2010:14).

Kata deiksis dapat diketahui rujukannya apabila mengetahui konteks tuturan. Konteks adalah latar belakang pengetahuan yang sama dimiliki oleh tutur dan mitra tutur. Tuturan dalam bahasa Indonesia terdapat dua jenis yakni tuturan lisan dan tuturan tulisan. Tuturan lisan yakni tuturan yang berupa bahasa menggunakan mulut dan mengeluarkan bunyi. Tuturan lisan dapat ditemukan ketika seseorang berbicara. Sedangkan tuturan tulis yakni tuturan yang dituliskan atau dicetak menggunakan bahasa tulis maupun cetak. Pada penelitian ini peneliti mengambil objek tuturan tulis pada sebuah karya sastra yakni novel. 
Novel adalah karangan prosa yang panjang mengandung rangkaian cerita kehidupan seseorang dengan orang di sekelilingnya dengan menonjolkan watak dan sifat pelaku. Novel Sang pemimpi karya Andrea Hirata menceritakan perjalanan hidup dari pengarang mengenai masa kecil yang dihabiskannya di tanah kelahirannya yaitu pulau Belitong. Budaya Melayu Belitong dengan kemiskinan masyarakat daerah pertambangan menjadi warna yang pekat melatarbelakangi kisah yang dituturkannya.

Dalam novel Sang Pemimpi Karya Andrea Hirata terdapat deiksis di antaranya deiksis persona, deiksis waktu, deiksis tempat, deiksis sosial, dan deiksis wacana. Dari sekian deiksis yang terdapat dalam novel Sang Pemimpi Karya Andrea Hirata yang paling banyak muncul yakni deiksis persona.

Novel Sang Pemimpi karya Andrea Hirata dipilih sebagai sumber data karena peneliti merasa tertarik pada alur cerita yang diuraikan oleh pengarang tentang tokoh Jimron, Arai dan Ikal. Novel ini memberi inspirasi mengenai kisah anak yang memiliki cita-cita yang tinggi. Ketiga tokoh dalam novel Sang Pemimpi Karya Andrea Hirata, mereka bertekad akan sukses jika mereka berusaha. Mereka melewati berbagai rintangan untuk melanjutkan mimpi dan hidupnya.

Tokoh dalam novel Sang Pemimpi karya Andrea Hirata menggunakan deiksis sebagai ciri gramatikal dan leksikal yang menghubungkan ujaran dan jalinan persona, ruang, waktu, wacana, sosial, dalam tindak ujaran. Penggunaan deiksis digunakan oleh pengarang apabila tidak dipahami oleh pembaca tentu akan membuat pembaca sulit untuk memahami isi cerita pada novel.

Penelitian tentang deiksis dilakukan karena dalam linguistik belum banyak peneliti bahasa yang menelitinya. Deiksis dalam sebuah novel menjadi hal yang penting untuk diteliti karena novel sebagai suatu karya sastra yang menampilkan dialog dan percakapan antartokoh sehingga memungkinkan adanya deiksis (Damayanti, 2013). Gaya dialog yang digunakan pada novel menggunakan deiksis yang referennya berganti-ganti atau berpindah-pindah bergantung pada yang menjadi pembicara, serta waktu dan tempat dituturkannya suatu kata. Supaya dapat memahami kalimat yang mengandung deiksis, dibutuhkan konteks linguistik dalam novel Sang Pemimpi Karya Andrea Hierata. Pengetahuan mengenai penggunaan deiksis pada novel diperlukan apabila ingin memahami kisah yang disampaikan pada novel.

Deiksis termasuk bagian dari pragmatik, di dalam pragmatik tercakup bahasan tentang deiksis, praanggapan, tindak tutur, dan implikatur percakapan. Kata deiksis berasal dari bahasa Yunani deiktikos, yang berarti hal penunjukan secara langsung. Sebuah kata dikatakan deiksis 
apabila referen atau rujukannya berpindah-pindah atau bergantiganti bergantung pada siapa yang menjadi si pembicara atau bergantung pada saat dan tempat dituturkannya kata itu, (Purwo, 2000:1-2).

Menurut Yule (2006:13) deiksis adalah istilah teknis (dari bahasa Yunani) untuk salah satu hal mendasar yang kita lakukan dengan tuturan. Deiksis berarti 'penunjukan' melalui bahasa. Bentu linguistik yang dipakai untuk menyelesaikan 'penunjukan' disebut dengan ungkapan deiksis. Fenomena deiksis merupakan cara yang paling jelas untuk menggambarkan hubungan antara bahasa dan konteks di dalam struktur bahasa itu sendiri (Djajasudarma: 2012:50).

Deiksis adalah kata atau frase yang menghubungkan langsung ujaran kepada sebuah tempat, waktu, orang atau persona. Kata yang bersifat deiksis mempunyai rujukan yang berbeda-beda dan berganti-ganti bergantung pada siapa pembicaranya, waktu, dan tempat sebuah ujaran berlangsung. Deiksis adalah bentuk bahasa baik berupa kata maupun lainnya yang berfungsi sebagai penunjuk hal atau fungsi tertentu di luar bahasa. Dengan kata lain, sebuah bentuk bahasa bisa dikatakan bersifat deiksis apabila acuan/ rujukan/ referennya berpindah-pindah atau berganti-ganti pada siapa yang menjadi si pembicara dan bergantung pula pada saat dan tempat dituturkannya kata itu. Jadi, deiksis merupakan kata-kata yang tidak memiliki referen yang tetap.

\section{METODE PENELITIAN}

Penelitian ini menggunakan pendekatan deskriptif kualitatif. Pendekatan deskriptif dapat digunakan untuk memberikan, menggambarkan, menguraikan dan menjelaskan fenomena objek penelitian. Penelitian kualitatif merupakan prosedur penelitian yang menghasilkan data deskriptif berupa kata-kata tertulis tentang sifat-sifat individu, keadaan gejala, dari kelompok tertentu yang dapat diamati.

Penelitian kualitatif adalah penelitian yang menghasilkan prosedur analisis yang tidak menggunakan prosedur analisis statistik atau cara kuantifikasi lainnya (Moleong, 2011:6). Penelitian kualitatif dilakukan pada kondisi alamiah dan bersifat penemuan. Penelitian kualitatif digunakan jika masalah masih belum jelas, untuk mengetahui makna yang tersembunyi, untuk memahami interaksi sosial, untuk mengembangkan teori, untuk memastikan kebenaran data dan meneliti sejarah perkembangan. Menurut Moleong (2011:8) penelitian kualitatif memiliki 11 karakteristik yaitu: (1) latar alamiah (2) manusia sebagai alat (instrumen) (3) metode kualitatif (4) analisis data secara induktif (5) teori dari dasar (grounded theory) (6) deskriptif (7) lebih mementingkan proses daripada hasil (8) adanya batas yang ditentukan oleh fokus (9) adanya kriteria khusus untuk keabsahan data (10) desain yang 
bersifat sementara (11) hasil penelitian dirundingkan dan disepakati bersama.

Dalam hal ini peneliti tidak hanya membaca dan mendeskripsikan deiksis pada novel Sang Pemimpi Karya Andrea Hirata tetapi peneliti juga memahami isi dari novel Sang Pemimpi Karya Andrea Hirata yakni berupa deiksis.

Menurut Lofland dan Lofland (dalam Moleong, 2011:157) data utama dalam penelitian kualitatif ialah kata-kata, dan tindakan, selebihnya adalah data tambahan seperti dokumen dan lain-lain. Data dalam penelitian ini meliputi kata maupun kalimat yang mengandung deiksis yang ada dalam novel Sang Pemimpi Karya Andrea Hirata. Deiksis yang terdapat dalam novel Sang Pemimpi karya Andera Hirata diantaranya deiksis persona, deiksis tempat, deiksis waktu, deiksis sosial, dan deiksis wacana.

Sedangkan Sumber data adalah subjek dari mana data dapat diperoleh. Sumber data yang diperoleh dalam penelitian ini ialah novel Sang Pemimpi karya Andrea Hirata.

Teknik pengumpulan data adalah suatu cara yang digunakan untuk memeroleh informasi atau bukti-bukti yang berfungsi sebagai dasar penelitian. Teknik pengumpulan data yang dipakai dalam penelitian ini ialah membaca dan mencatat.

Langkah-langkah yang ditempuh dalam pengumpulan data ialah sebagai berikut:
1) Membaca secara teliti novel Sang Pemimpi karya Andrea Hirata yang menjadi sumber data.

2) Membaca disertai memberi tanda pada kata yang diduga sebagai deiksis.

Teknik analisis data yang dilakukan dalam penelitian ini, sebagai berikut:

1. Identifikasi data yang mengandung deiksis yang terdapat dalam novel Sang Pemimpi karya Andrea Hirata. Identifikasi data dilakukan untuk memahami objek yang akan diteliti. Hal yang pertama kali dilakukan dalam penelitian ini yakni membaca berulang-ulang kemudian memilih data penelitian yang sesuai dengan rumusan masalah.

2. Klasifikasi data yang mengandung deiksis yang terdapat dalam novel Sang Pemimpi karya Andrea Hirata. Data yang terkumpul dapat diklasifikasikan berdasarkan jenisnya. Data yang diklasifikasikan sesuai dengan rumusan masalah.

3. Deskripsikan data yang terdapat dalam novel Sang Pemimpi karya Andrea Hirata. Data yang telah diklasifikasikan kemudian dideskripsikan, memaparkan sesuai dengan teori yang telah tertera di kajian pustaka.

4. Menyimpulkan hasil temuan sesuai dengan masalah penelitian. Dari ketiga tahap yang telah peneliti lakukan, maka langkah selanjutnya 
peneliti menarik simpulan atas apa yang telah dipaparkan sesuai dengan rumusan masalah.

\section{HASIL DAN PEMBAHASAN}

Fenomena deiksis merupakan cara yang paling jelas untuk menggambarkan hubungan antara bahasa dan konteks di dalam struktur bahasa itu sendiri. Dalam penelitian ini objek yang diteliti adalah Penggunaan Deiksis pada Novel Sang Pemimpi Karya Andrea Hiarata. Aspek-aspek yang menjadi perhatian dalam penelitian ini yakni jenis-jenis deiksis yang terdapat dalam Novel Sang Pemimpi Karya Andrea Hiarata.

\section{Penggunaan Deiksis Persona}

Deiksis persona berkaitan dengan peran peserta yang terlibat dalam peristiwa berbahasa. Deiksis ini biasanya berupa kata ganti orang. Pronomina ada tiga kategori yaitu orang pertama, orang kedua, dan orang ketiga.

Pronomina orang pertama merupakan rujukan pembicara kepada dirinya sendiri. Dengan kata lain pronomina persona pertama merujuk pada orang yang sedang berbicara. Pronomina persona ini dibagi menjadi dua yaitu persona pertama tunggal dan persona pertama jamak. Pronomina persona pertama tunggal memunyai beberapa bentuk yaitu, aku, saya, daku.

Pronomina persona kedua adalah rujukan kepada lawan bicara. Dengan kata lain bentuk pronomina persona keduabaik tunggal maupun jamak merujuk kepada lawan bicara. Bentuk pronomina persona kedua adalah kamu, engakau. Pronomina

persona ketiga merupakan kategorisasi rujukan pembicara kepada orang yang berada di luar tindak komunikasi. Dengan kata lain bentuk pronomina persona ketiga merujuk orang yang tidak berada baik pada pihak pembicara maupun lawan bicara. Bentuk kata ganti persona ketiga dalam bahasa Indonesia ada dua, yaitu bentuk tunggal dan bentuk jamak. Bentuk tunggal pronomina persona ketiga mempunyai dua bentuk, yaitu ia dan dia yang mempunyai variasinya.Bentuk pronomina persona ketiga jamak adalah mereka Di samping arti jamaknya, bentuk mereka berbeda dengan pronomina persona ketiga tunggal dalam acuannya.

a. Pronomina Orang Pertama Tunggal

Kalimat menggunakan kata $a k u$ di bawah merujuk pada pembicara atau dirinya sendiri. Hal ini ditandai pada kutipan novel Sang Pemimpi karya Andrea Hirata berikut:

Aku meliriknya kejam. Mendengar ocehannya, ingin rasanya aku mencongel 
gembok peti es untuk melemparnya.

Dari data ke (1) pada novel Sang Pemimpi karya Andrea Hirata terdapat deiksis persona pronomina orang pertama tunggal. Deiksis persona pertama tunggal aku yang terdapat dalam novel Sang Pemimpi karya Andrea Hirata menunjukkan seorang tokoh yang bernama Ikal.. Dari kutipan data pada novel Sang Pemimpi karya Andrea Hirata tersebut kata yang dicetak tebal menunjukan deiksis persona pertama tunggal. Pada data ke (1) pada novel Sang Pemimpi karya Andrea Hirata pembicara membicarakan dirinya sendiri kepada pembaca atau pendengar.

b. Pronomina Orang Kedua Tunggal

Kata $k a u$ dalam kalimat di bawah merujuk pada pendengar, atau lebih dari satu orang. Dilihat pada kutipan novel Sang Pemimpi karya Andrea Hirata berikut:

“Tidak adil! Ini idemu, Rai, kau masuk duluan!"

Dari data tersebut pada novel Sang Pemimpi karya Andrea Hirata terdapat deiksis persona pronomina orang kedua tunggal. Dari data tersebut deiksis pronomina orang kedua tunggal kau menunjukkan seorang tokoh yang bernama Arai. Dari data tersebut pada novel Sang Pemimpi karya Andrea Hirata pembicara berbicara dengan lawan bicaranya.

c. Pronomina Orang Ketiga Tunggal

Kata dia dalam kalimat di bawah merujuk pada yang bukan pembicara dan bukan pendengar. Seperti dalam kutipan novel Sang Pemimpi karya Andrea Hirata di bawah ini.

"Dia melirikku yang terjepit tak berdaya, senyumnya semakin girang."

Dari data tersebut pada novel Sang Pemimpi karya Andrea Hirata terdapat deiksis persona pronomina orang ketiga tunggal. Data tersebut deiksis persona ketiga tunggal dia yang terdapat dalam novel Sang Pemimpi karya Andrea Hirata menunjukkan tokoh bernama Arai.

Data tersebut pada novel Sang Pemimpi karya Andrea Hirata deiksis persona pronomina orang ketiga tunggal dapat ditunjukan pada kata yang dicetak tebal. Data pada novel Sang Pemimpi karya Andrea Hirata digunakan oleh orang yang bukan pembicara kepada pembaca atau pendengar.

d. Pronomina Pertama Jamak

Kata kami yang ada pada contoh dalam kalimat di bawah merujuk pada orang yang 
sedang berbicara dalam penggalan kalimat tersebut. Seperti dalam kutipan novel Sang Pemimpi karya Andrea Hirata di bawah ini:

"Bayangan tiga orang pria berkelebat, memutus pedagang cahaya tadi dan sekarang pemisah kami dengan nasib buruk hanya beberapa keping papan tipis."

Dari data tersebut pada novel Sang Pemimpi karya Andrea Hirata terdapat deiksis persona pertama jamak. Data tersebut deiksis persona pertama jamak kami menunjukkan tokoh yang terdapat pada novel Sang Pemimpi Karya Andrea Hirata yang bernama Ikal, Arai, Jimbron. Dari data tersebut deiksis persona pertama jamak yang terdapat pada novel Sang Pemimpi karya Andrea Hirata ditandai dengan kata yang dicetak tebal. Data tersebut pada novel Sang Pemimpi karya Andrea Hirata digunakan oleh pembicara itu sendiri kepada pembaca atau pendengar.

Kata kita dalam kalimat di bawah mengacu pada beberapa orang atau lebih pada saat dituturkannya kata itu. Seperti kutipan novel Sang Pemimpi karya Andrea Hirata berikut:

"Jika menonton TVRI, kita biasa melihat orang seperti Arai meloncat-loncat di belakang pesiden agar tampak oleh kamera."

Pada data tersebut pada novel Sang Pemimpi karya Andrea Hirata terdapat deiksis persona pertama jamak. Data tersebut deiksis persona pertama jamak kita menunjukkan tokoh yang terdapat dalam novel Sang Pemimpi karya Andrea Hirata yakni aku dan lawan bicaranya (Arai, Jimbron). Dari data tersebut deiksis persona pertama jamak yang terdapat dalam novel Sang Pemimpi karya Andrea Hirata ditandai dengan kata yang dicetak tebal. Data tersebut digunakan oleh pembicara itu sendiri kepada pembaca atau pendengar.

e. Pronomina Kedua Jamak

Kata kalian dalam kalimat di bawah mengacu pada beberapa orang atau lebih pada saat dituturkannya bahasa itu. Seperti pada kutipan novel Sang Pemimpi karya Andrea Hirata berikut:

"Preambul: "Kalian tak tahu apa-apa soal kesulitan hidup, kecuali kalian hidup di zaman Jepang."

Data tersebut deiksis persona kedua jamak kalian menunjukkan tokoh yang terdapat dalam novel Sang Pemimpi karya Andrea Hirata yakni Aku, Arai dan Jimbron. Dari data tersebut deiksis persona kedua jamak kalian yang terdapat dalam dalam 
datatersebut pada novel Sang Pemimpi karya Andrea Hirata ditandai dengan kata yang dicetak tebal. Data tersebut digunakan untuk membicarakan orang lain yang mengacu kepada orang yang lebih dari satu saat dituturkannya bahasa itu.

f. Pronomina Ketiga Jamak

Kata mereka dalam kalimat di bawah, bukan pembicara dan bukan pula pendengar. Seperti dalam kutipan novel Sang Pemimpi karya Andrea Hirata berikut:

"Ratusan tahun mereka menanggung sakit hati."

Dari data tersebut pada novel Sang Pemimpi karya Andrea Hirata terdapat deiksis persona ketiga jamak. Data tersebut deiksis persona ketiga jamak mereka menunjukkan tokoh yang terdapat dalam novel Sang Pemimpi karya Andrea Hirata yakni para prajurit, Tionghoa. Dari data tersebut deiksis persona ketiga jamak pada novel Sang Pemimpi karya Andrea Hirata ditandai dengan kata yang dicetak tebal. Data tersebut pada novel Sang Pemimpi karya Andrea Hirata digunakan oleh orang yang bukan pembicara dan bukan pukan pula pendengar.

\section{Penggunaan Deiksis Tempat}

Deiksis ini berkaitan dengan pemberian bentuk kepada lokasi ruang dipandang dari lokasi pemeran dalam suatu peristiwa berbahasa. Dilihat dari hubungan antara orang dan benda yang ditunjukkan, deiksis tempat dibagi menjadi dua, yaitu jauh (distal) dan dekat (proksimal). Deiksis tempat yang pertama menunjuk jarak yang jauh antara orang dan benda yang ditunjukkan seperti di sana, itu, dan sebagainya. Deiksis tempat yang kedua menunjuk jarak yang dekat antara orang dan benda yang ditunjukkan seperti di sini, di situ. Deiksis ini merupakan pemberian bentuk pada lokasi atau ruang yang merupakan tempat, dipandang dari lokasi pemeran dalam peristiwa berbahasa atau merujuk pada lokasi, ruang, atau tempat. Misalnya; di sini, di situ, di sana

a. Deiksis Tempat "di sini".

Dalam kalimat yang mengandung kata di sini di bawah, mengacu pada yang dekat dengan pembicara. Seperti dalam kutipan novel Sang Pemimpi karya Andrea Hirata di bawah ini.

"Lalu di sini,di sudut dermaga ini, aku terkurung mati kutu."

Dari data tersebut pada novel Sang Pemimpi karya Andrea Hirata terdapat deiksis tempat. Data tersebut deiksis tempat di sini mengacu kepada tempat berlangsungnya penuturan yakni di sudut dermaga. Deiksis tempat pada novel Sang Pemimpi karya Andrea Hirata pada data tersebut ditandai dengan kata yang dicetak tebal. 
b. Deiksis Tempat "di situ".

Kata di situ dalam kalimat ini, yang bukan dekat dengan pembicara, namun dekat dengan pandangan. Seperti dalam kutipan novel Sang Pemimpi karya Andrea Hirata berikut ini.

"Daripada kalian merokok saja di situ, aya ya ... tak berguna!"

Dari data tersebut pada novel Sang Pemimpi karya Andrea Hirata terdapat deiksis tempat. Data tersebut deiksis tempat di situ mengacu kepada tempat yang bisa dipandang saat berlangsungnya penuturan yakni di luar gudang. Deiksis tempat pada novel Sang Pemimpi karya Andrea Hirata pada data tersebut ditandai dengan kata yang dicetak tebal.

\section{Penggunaan Deiksis Waktu}

Deiksis waktu menunjuk kepada pengungkapan jarak waktu dipandang dari waktu atau saat suatu ungkapan dibuat oleh pembicara seperti sekarang, pada saat itu, kemarin, besok dan lain sebagainya. Semua ungkapan tersebut tergantung pada pemahaman penutur tentang pengetahuan waktu tuturan yang relevan. Jika waktu tuturan tidak diketahui dari suatu catatan, ada ketidakjelasan dalam hal waktu, contoh kembalilah satu jam lagi. Landasan psikologis dari deiksis waktu tampaknya sama dengan deiksis tempat. Kejadian waktu dapat diperlakukan sebagai yang bergerak ke penutur atau sebaliknya.

Deiksis waktu adalah pemberian bentuk kepada titik atau jarak dipandang dari waktu atau saat suatu ungkapan dibuat. Misalnya; kini, kemarin, lusa, sekarang, besok, dulu, tadi, nanti.

a. Deiksis Waktu "kini".

Kata kini dalam kalimat ini mengacu pada waktu dituturkannya kalimat tersebut. Seperti dalam kutipan novel Sang Pemimpi karya Andrea Hirata berikut:

"Kini, dimusuhi bangsa sendiri, dikhianati Belanda, dan di jauhi orang Melayu membuat mereka curiga kepada siapu pun."

Data tersebut pada novel Sang Pemimpi karya Andrea Hirata terdapat deiksis waktu. Dari data tersebut deiksis waktu kini mengacu ke waktu saat berlangsungnya penuturan. Akan tetapi deiksis waktu kini yang tedapat dalam novel Sang Pemimpi karya Andrea Hirata tidak ditandai dengan detik, menit atau pun jam pada saat berlangsungnya penuturan. Deiksis waktu dari data tersebut pada novel Sang Pemimpi karya Andrea Hirata ditandai dengan kata yang dicetak tebal.

b. Deiksis Waktu pada kata "sekarang". 
Dalam kalimat di bawah, kata sekarang merujuk pada saat dituturkannya penuturan, atau merujuk ke jam atau bahkan menit. Hal inilah yang disebut deiksis yang cakupannya selalu mencakupi saat peristiwa pembicaraan. Seperti dalam kutipan novel Sang Pemimpi karya Andrea Hirata berikut:

"Bayangan tiga orang pria berkelebat, memutus pedagang cahaya tadi dan sekarang pemisah kami dengan nasib buruk hanya beberapa keping papan tipis."

Data tersebut pada novel Sang Pemimpi karya Andrea Hirata terdapat deiksis waktu. Dari data tersebut deiksis waktu sekarang mengacu ke waktu saat berlangsungnya penuturan. Akan tetapi deiksis waktu sekarang yang tedapat dalam novel Sang Pemimpi karya Andrea Hirata tidak ditandai dengan detik, menit atau pun jam pada saat berlangsungnya penuturan. Deiksis waktu dari data tersebut pada novel Sang Pemimpi karya Andrea Hirata ditandai dengan kata yang dicetak tebal.

c. Deiksis Waktu "dulu".

Kata dulu pada kalimat di bawah mengacu pada waktu, yaitu merujuk lebih jauh kebelakang mungkin yang sudah bertahun-tahun lamanya. Seperti terlihat dalam kutipan novel Sang Pemimpi karya Andrea Hirata berikut:

"Dulu kami harus sekolah ke Tanjung Pandan, ratusan kilo meterjauhnya."

Data tersebut pada novel Sang Pemimpi karya Andrea Hirata terdapat deiksis waktu. Dari data tersebut deiksis waktu dulu mengacu ke waktu yang telah lampau atau telah lama dilewati. Akan tetapi deiksis waktu dulu yang terdapat dalam novel Sang Pemimpi karya Andrea Hirata tidak ditandai dengan tahun saat berlangsungnya penuturan. Deiksis waktu pada data tersebut pada novel Sang Pemimpi karya Andrea Hirata ditandai dengan kata yang dicetak tebal.

d. Deiksis Waktu "tadi".

Kata tadi dalam kalimat ini mengacu ke waktu sebelum dituturkannya kata itu, yakni kata yang diucapkan tidak terlalu lama, atau beberapa menit yang lalu. Hal ini terlihat pada kutipan novel pada novel Sang Pemimpi karya Andrea Hirata berikut:

Bayangan tiga orang pria berkelebat, memutus pedagang cahaya tadi dan sekarang pemisah kami dengan nasib buruk hanya beberapa keping papan tipis.

Dari data tersebut pada novel Sang Pemimpi karya Andrea Hirata terdapat deiksis 
waktu. Data tersebut deiksis waktu tadi mengacu ke waktu yang belum lama dilewati. Akan tetapi deiksis waktu tadi yang terdapat dalam novel Sang Pemimpi karya Andrea Hirata tidak ditandai dengan detik, menit, maupun jam saat berlangsungnya penuturan. Deiksis waktu pada data tersebut pada novel Sang Pemimpi karya Andrea Hirata ditandai dengan kata yang dicetak tebal.

\section{Penggunaan Deiksis Wacana}

Deiksis wacana merupakan deiksis yang mengacu apa yang terdapat dalam wacana. Berdasarkan posisi antensendennya, deiksis wacana dibagi dua,yaitu anafora dan katafora. Deiksis anafora merupakan deiksis yang mengacu apa yang telah disebut, sedangkan deiksis katafora adalah deiksis yang mengacu yang akan disebut Jadi, pembagian bentuk kepada bagian-bagian tertentu dalam wacana yang telah disebut, yang telah diuraikan atau yang sedang dikembangkan. Dalam ilmu bahasa gejala ini disebut anafora, yaitu yang menunjuk kepada yang sudah disebut dan katafora, yaitu yang menunjuk kepada yang akan disebut. Misalnya; ini, itu, yang terdahulu (anafora), yang berikut, dibawah ini, sebagai berikut (katafora)

\section{a. Anafora}

Pada kalimat anafora di bawah terdapat enklitik-nya, dan enklitik-nya ini mengacu kepada Nyonya Pho, Arai. Hal ini terlihat dalam kutipan novel Sang Pemimpi karya Andrea Hirata berikut:

Pertama; Nyonya Pho bertubuh tinggi besar. Rambutnya tebal, disemir hitam pekat dan kaku seperti sikat. Alisnya seperti kucing tandang. Bahunya tegap , dadannya tinggi, dan raut mukanya seperti orang terkejut. Sesuai tradisi Ho Pho, dia bertat, lukisan naga menjalar dari punggung sampai ke bawah telinga, bersurai-surai dengan tinta cina. Bengis, tega, sok kuasa, dan tak mau kalah tersirat jelas dari matanya. bertubuh tinggi besar. Rambutnya tebal, disemir hitam pekat dan kaku seperti sikat. Alisnya seperti kucing tandang. Bahunya tegap , dadannya tinggi, dan raut mukanya seperti orang terkejut. Sesuai tradisi Ho Pho, dia bertat, lukisan naga menjalar dari punggung sampai ke bawah telinga, bersurai-surai dengan tinta cina. Bengis, tega, sok kuasa, dan tak mau kalah tersirat jelas dari matanya. Kedua; Arai adalah sebatang pohon kara di tengah karena hanya tinggal dia sendiri dari satu garis keturunan keluarganya. Ayahibunya merupakan anak-anak tunggal dan kakek-neneknya dari kedua pihak orangtuanya juga telah tiada.

Pada kedua data tersebut terdapat deiksis wacana anafora. Data pertama 
menunjukkan tokoh yang terdapat dalam novel Sang Pemimpi karya Andrea Hirata yakni Nyonya Pho. Enklitik nya menggantikan nama tokoh (Nyonya Pho) yang telah ada pada kata atau kalimat sebelumnya. Data kedua menunjukkan tokoh yang terdapat dalam novel Sang Pemimpi karya Andrea Hirata yakni Arai. Enklitiknya nya dan dia menggantikan tokoh (Arai) yang telah ada pada kata atau kalimat sebelumnya.

Dari data pada novel Sang Pemimpi karya Andrea Hirata deiksis wacana anafora ditandai dengan adanya sebutan untuk menggantikan kata yang ada sebelumnya. Hal ini ditandai dengan adanya kata yang dicetak tebal.

\section{b. Katafora}

Pada kalimat katafora di bawah terdapat enklitik-nya, dan enklitik-nya ini mengacu kepada Arai. Hal ini terlihat dalam kutipan novel Sang Pemimpi karya Andrea Hirata berikut:

Pertama; Di luar jendela kamarnya, Arai akan melantunkan When I Fall in Love. Kedua; ketika dia berbalik, aku membaca nama pada emblem hitam murahan yang tersemat di dadanya:

\section{MUSTAR M. DJAI'DIN,B.A.}

Pada kedua data tersebut terdapat deiksis wacana katafora. Data pertaman menunjukkan tokoh yang terdapat dalam novel Sang
Pemimpi karya Andrea Hirata yakni Arai. Enklitik nya menggantikan nama tokoh (Arai) yang belum ada pada kata atau kalimat sebelumnya. Data kedua menunjukkan tokoh yang terdapat dalam novel Sang Pemimpi karya Andrea Hirata yakni Pak Mustar. Enklitik nya menggantikan tokoh (pak Mustar) yang belum ada pada kata atau kalimat sebelumnya.

Dari data pada novel Sang Pemimpi karya Andrea Hirata deiksis wacana katafora ditandai dengan adanya sebutan untuk menggantikan kata yang ada sesudahnya. Hal ini ditandai dengan adanya kata yang dicetak tebal.

\section{Penggunaan Deiksis Sosial}

Deiksis sosial mengungkapkan perbedaan-perbedaan

kemasyarakatan yang terdapat antarpartisipan yang terlibat dalam peristiwa berbahasa. Deiksis ini menyebabkan adanya kesopanan berbahasa. Deiksis sosial juga mengungkapkan atau menunjukkan perbedaan ciri sosial antara pembicara dan lawan bicara atau penulis dan pembaca dengan topik atau rujukan yang dimaksud dalam pembicaraan itu (Agustina, 1995:50). Deiksis sosial juga ditunjukkan oleh sistem honorifiks (sopan santun berbahasa). Misalnya penyebutan pronomina persona (kata ganti orang), seperti kau, kamu, dia, dan mereka, serta penggunaan sistem sapaan dan penggunaan gelar. Hal ini terlihat 
pada kutipan novel Sang Pemimpi karya Andrea Hirata berikut:

Pertama; Ketika dia berbalik, aku membaca nama pada emblem hitam murahan yang tersemat di dadanya: MUSTAR M. DJAI'DIN,B.A. Kedua; Penumpang vespa itu adalah Nyonya Lam Nyet Pho, turunan prajurit Ho Pho.

Dari kedua data tersebut pada novel Sang Pemimpi karya Andrea Hirata terdapat deiksis sosial. Data pertama menunjukkan kesetaraan sosial dari seorang tokoh yang terdapat pada novel Sang Pemimpi karya Andrea Hirata. Kesetaraan sosial dari seorang tokoh yang terdapat dalam novel Sang Pemimpi karya Andrea Hirata ditandai dengan adanya Gelar B.A. dari Pak Mustar. Data kedua menunjukkan kesetaraan sosial dari seorang tokoh yang terdapat pada novel Sang Pemimpi karya Andrea Hirata. Kesetaraan sosial dari seorang tokoh yang terdapat dalam novel Sang Pemimpi karya Andrea Hirata ditandai dengan adanya sebutan untuk Nyonya Lam Nyet Pho

Deiksis sosial yang terdapat pada kedua data tersebut ditandai oleh kata yang bercetak tebal. Kata yang bercetak tebal menunjukan sebutan tingkatan sosial dari tokoh yang terdapat dalam kutipan novel Sang Pemimpi karya Andrea Hirata.
Hasil analisis data menunjukkan bahwa penggunaan deiksis dalam novel Sang Pemimpi karya Andrea Hirata memiliki hubungan makna tertentu antara bagian-bagiaannya yang membentuk satu kesatuan makna, sehingga wacana deiktif merupakan referen dengan wacana sebelumnya karena masing-masing deiktif tercipta melalui hubungan antarmakana kata. Deiksis yang digunakan dalam novel Sang Pemimpi karya Andrea Hirata terdiri atas lima jenis. Dalam penelitian ini, peneliti kaitkan dengan teori yang dikemukakan oleh Purwo (dalam Pateda 1991:178) bahwa terdapat lima jenis deiksis.

Pertama. penggunaan deiksis persona meliputi deiksis persona pertama tunggal (aku) deiksis persona kedua tunggal (kau), deiksis persona ketiga tunggal (dia), deiksis pertama jamak (kita, kami), deiksis kedua jamak (kalian) dan deiksis ketiga jamak (mereka). Kedua, penggunaan deiksis tempat meliputi di sini, dan di situ. Ketiga, penggunaan deiksis waktu meliputi waktu lampau (dulu, tadi) sebagaimana waktu terjadinya pengujaran telah lewat, waktu terjadinya tuturan itu (kini, sekarang) sebagaimana waktu sedang berlangsungnya suatu situasi bersamaan dengan pengujarannya. Keempat, penggunaan deiksis wacana meliputi anafora dan katafora. Kelima penggunaan deiksis sosial yakni mengungkapkan atau menunjukkan perbedaan ciri sosial antara pembicara dan lawan bicara 
atau penulis dan pembaca dengan topik atau rujukan yang dimaksud dalam pembicaraan itu.

\section{SIMPULAN}

Berdasarkan hasil analisis data mengenai deiksis pada novel Sang Pemimpi karya Andrea Hirata ditemukan lima jenis deiksis terdiri atas deiksis persona, deiksis tempat, deiksi waktu, deiiksis wacana dan deiksis sosial. Dalam penelitian ini, deiksis persona lebih banyak ditemukan. Deiksis persona memiliki enam bagian di antaranya; pronomina orang pertama tunggal (aku), pronomina orang kedua tunggal (kau), pronomina orang ketiga tunggal (dia), pronomina pertama jamak (kami, kita), pronomina kedua jamak (kalian), pronomina ketiga jamak (mereka).

Deiksis tempat yang ditemukan dalam penelitian ini di antaranya; di sini, di situ, di pasar kumuh. Deiksis waktu yang ditemukan dalam penelitian ini diantaranya kini, sekarang, tadi, dulu. Deiksis wacana yang ditemukan diantaranya anafora dan katafora. Sedangkan deiksis sosial yang ditemukan dalam penelitian ini diantaranya Nyonya, dan B.A.

\section{DAFTAR PUSTAKA}

Damayanti, Rini. 2013. Penggunaan Deiksis Semantik dalam Cerpen Siluet Jingga Karya Anggi P. Jurnal Buana Bastra 2 (2), 175187
Djajasudarma. 2012. Wacana dan Pragmatik. Bandung: PT Refika Aditama.

Fitria, Rifanisa Nurul, 2010. "Deiksis dalam bahasa Indonesia seorang anak berusia 45 bulan: sebuah studi kasus". Skripsi. Depok: Universitas Indonesia.

Hirata, Andrea. 2006. Sang Pemimpi. Yogyakarta: Bentang.

Kridalaksana, Harimurti. 2008. Bahasa dan Linguistik. Jakarta: PT Gramedia Pustaka Utama.

Kushartanti,dkk. 2015. Pesona Bahasa: Langkah Awal Memahami Linguistik. Jakarta: Gramedia.

Moleong,Lexy.2011.Metodologi Penelitian Kualitatif.Bandung: PT Remaja Rosdakarya.

Purwo, Bambang Kaswanti. 2000. Deiksis dalam Bahasa Indonesia. Jakarta:

Balai Pustaka.

Tarigan. 2008. Pengajaran Pragmatik: Bandung: Angkasa.

Yule, G. 2006. Pragmatik. Terjemahan. Yogyakarta: Pustaka Pelajar. 